\title{
Influence of variability in the amount of inflow wastewater pollution concentration in small sewer system (case study)
}

\author{
Karolina Kurek ${ }^{1, *}$, Piotr Bugajski ${ }^{I}$, Agnieszka Operacz ${ }^{1}$, Paulina Śliz ${ }^{2}$, and Krzysztof Jóźwiakowski ${ }^{3}$ \\ ${ }^{1}$ University of Agriculture in Krakow, Faculty of Environmental Engineering and Land Surveying, Department of Sanitary \\ Engineering and Water Management, Al. Mickiewicza 21, 31-120 Krakow, Poland \\ ${ }^{2}$ Krakow University of Economics, Rakowicka 27, 31-510 Krakow, Poland \\ ${ }^{3}$ University of Life Sciences in Lublin, Akademicka 13, 20-033 Lublin, Poland
}

\begin{abstract}
The aim of study was the analyze of the impact of hydraulic load on the changes in the concentration of pollution indicators in raw sewage in years 2009-2014 in the small wastewater treatment plant. Qualitative analysis for raw sewage was included three parameters: total suspension solid, BOD and COD. The characteristics relation between the concentration of pollution indicators in raw sewage (depend variable) from the hydraulic load(independent variable) was presented by the Pearson linear correlation. In the 6 year study period were collected 32 samples of raw wastewater. Based on the result of linear regression analysis, showed that along with the increasing amount of wastewater in the sewer decrease the concentration of pollutions in raw wastewater. For total suspension solid, increase by $1 \mathrm{~m}^{3}$ of quantity of raw sewage inflowing to wastewater treatment plant, causes a decrease in the concentration of this indicator by $0,53 \mathrm{~g} \cdot \mathrm{m}^{-3}$. For the both organic indicators (BOD and COD), the was found that an increase of $1 \mathrm{~m}^{3}$ the amount of raw sewage inflowing to wastewater treatment plant, caused a decrease of $0,75 \mathrm{gO}_{2} \cdot \mathrm{m}^{-}$ ${ }^{3} \mathrm{BOD}$ value and $0,66 \mathrm{gO}_{2} \cdot \mathrm{m}^{-3} \mathrm{COD}$ value in raw sewage.
\end{abstract}

\section{Introduction}

Economic development has contributed to the increase in the amount of water used and thus the amount of sewage generated. Thereby, in recent years, the problem of water and wastewater management has become a very important issue for both communes and voivodeships. The priority issues for local governments are these related to ecology, and thus the quality of sewage discharged into the environment [1-3]. The main threat to the natural environment is untreated sewage, which causes contamination of soil or water receivers. Discharging of untreated sewage to the receiver can cause many problems. One of them in the case of water receivers is oxygen decline as a result of mineralization of organic matter and nitrification processes [4-6].

One of the most important criteria regarding the effectiveness of the treatment plant is the amount of sewage discharged. The high variability of the amount of sewage on the inflow to the sewage treatment plant, as well as the unevenness of the concentration of organic compounds contained in it, affect the disruption of treatment processes in which it is important to maintain constant flow rates or sewage retention [2, 7-9]. The size of hydraulic load in the sewage treatment plant may change as a result of water saving, connection of new users, as well as the inflow of accidental water to the sewage system. The last one includes rainwater or snowmelt, which gets through the ventilation openings in the manholes to the inside of sewage wells, and is also illegally introduced from roof gutters. In addition, greater volume of sewage flowing into the treatment plant increases the operating costs resulting from the increase in energy consumption [10,11].

The method of biological wastewater treatment is one of the most commonly used wastewater treatment technologies. At the design stage, the selection of the optimal size of the bioreactor is an important aspect for the proper functioning of the activated sludge treatment plant. The factor which is directly considered by the designer is the amount of discharged sewage and the concentration of contaminants contained [12, 3, 20]. Large variations in the quantity and quality of incoming sewage contribute to the disruption of processes of proper metabolism of activated sludge microorganisms, and thus effective treatment plant operation [7, 10]. Excessive amounts of sewage entering the sewage treatment plant may cause danger of carrying the activated sludge from the bioreactor and problems with sedimentation in the secondary settling tank, which is a direct threat to the environment [13].

\section{Location of the object}

The facility study is locate in the commune of Mogilany in Lusina city, in south-eastern part of the Krakow district, and is working as one of two domestic

\footnotetext{
*Corresponding author: karolina.kurek.23@gmail.com
} 
wastewater treatment plant (Fig. 1). Effluent from the northern and central part of Libertow and parts of Lusina (around 500 homes) is divert to the wastewater treatment plant by the sewer collector with a diameter if $300 \mathrm{~mm}$. The object is working with the active sludge technology, which is one of the most popular and effective methods recommended to treated domestic wastes.

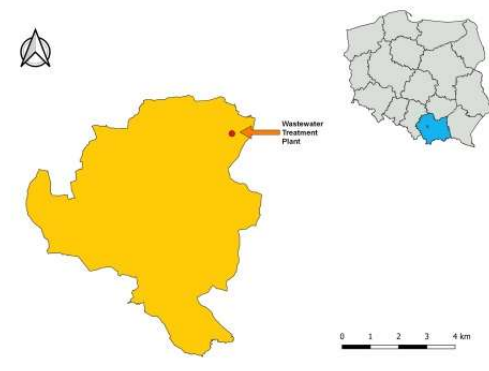

Fig. 1. Location of sewage treatment plant in the background of the Mogilany commune

\section{Materials and Methods}

At first the analysis was focused on hydraulic load for the Lusina sewage treatment plant and it was based on daily registers of the amount of sewage incoming to the facility in the period from 2009 to 2014. Additionally, during the six-year study period, 32 samples of raw sewage flowing into the treatment plant were collected, and they were subjected to physico-chemical analysis.

The analysis concerned pollution indicators from the basic group: $\mathrm{BOD}_{5}, \mathrm{COD}$ and total suspension. Physicochemical analyses were performed in accordance with the reference methods specified in the standards: for $\mathrm{BZT}_{5}$ - PN EN 1899-1: 2002 and PN EN 1899-2: 2002, for COD - PN-ISO 15705: 2005 and for total suspension - PN-EN 872 : 2007 + Ap1: 2007. There were determined such descriptive statistics as: positional measures - minimum, average and maximum values, measures of dispersion: standard deviation (s) and coefficient of variation $\left(\mathrm{V}_{\mathrm{s}}\right)$, as well as the measurement of the distribution of the studied variate: skewness (Sko) and kurtosis (Kurt) for both daily sewage volume and pollution indicators in sewage flowing into the treatment plant. For the hydraulic load in the considered test period, the value of the coefficient of maximum daily sewage inflow unevenness $\left(\mathrm{N}_{\mathrm{dmax}}\right)$ was determined in accordance with the formula $[14,15]$. In addition, there were determined histograms and empirical distributions of the volume of sewage flowing into the sewage treatment plant in 2009-2014. Class spans and their range have been determined using the formulas used, among others in the works [14]:

$$
N_{\text {dmax }}=\frac{Q_{\text {dmax }}}{Q_{\text {davg }}}
$$

where: $Q_{d \max }$ - maximum daily volume of treated sewage in the considered period of time $\left[\mathrm{m}^{3} \cdot \mathrm{d}^{-1}\right], Q_{\text {davg }}$ - average daily volume of treated sewage in the considered period of time $\left[\mathrm{m}^{3} \cdot \mathrm{d}^{-1}\right]$.
In addition, there were determined histograms and empirical distributions of the volume of sewage flowing into the sewage treatment plant in 2009-2014. Class spans and their range have been determined using the formulas [14]:

$$
L_{k}=5 \cdot \log N
$$

where: $L_{k}$ - number of right-open class intervals, $N-$ number of data in the observation sequence.

$$
\Delta=\frac{Q_{d \max }-Q_{d \min }}{L k}
$$

where: $\Delta$ - width of the class $\left[\mathrm{m}^{3} \cdot \mathrm{d}^{-1}\right], Q_{d \max }-$ maximum daily sewage volume inflowing to the treatment plant in the study period [maximum daily volume of treated sewage in the considered period of time $\left[\mathrm{m}^{3} \cdot \mathrm{d}^{-1}\right], Q_{d m i n}-$ minimum daily sewage volume inflowing to the treatment plant in the study period [maximum daily volume of treated sewage in the considered period of time $\left[\mathrm{m}^{3} \cdot \mathrm{d}^{-1}\right]$.

Based on the results of physico-chemical analyses of three indicators from the basic group in sewage flowing into the treatment plant and the average daily volume of sewage on the inflow, there was developed a correlation relationship between the impact of sewage volume and the size of pollution indicators in raw sewage. To this end, a statistical analysis of Pearson's rope correlation was used. As independent variables (x), the sewage volume was assumed, while the dependent variables $(\mathrm{y})$ were the values of a given pollution index. The range of the correlation coefficient was adopted in accordance with the scale proposed by Stanisz [1998] [16]. On the basis of the equations describing the regression lines, a unit range of changes in the concentration of the analyzed indicators was determined under the influence of the change in the volume of sewage flowing into the treatment plant.

\section{Study results}

The formation of daily sewage inflow to the wastewater treatment plant in Lusina in the years 2009 - 2014 is shown in the Figure 2. Specific descriptive statistics and the value of the maximum daily unevenness of sewage inflow presented in the Table 1, aimed at characterizing the dynamics of inflow changes for the tested object in the analyzed period. The analysis showed that the average daily volume of sewage flowing into the treatment plant was characterized by a spread of 329.7 $\mathrm{m}^{3} \cdot \mathrm{d}^{-1}$, with the average value of $262.2 \mathrm{~m}^{3} \cdot \mathrm{d}^{-1}$. The value of the coefficient of variation indicates the average variability of hydraulic load in the treatment plant in the analyzed multi-year. The skewness coefficient indicates the right-sided asymmetry of the analyzed variate, while the kurtosis value indicates its platocurtic distribution. The obtained $\mathrm{N}_{\mathrm{dmax}}$ value is close to the values given in the literature for small settlement units (below $5000 \mathrm{PE}$ ). In the work of Myszograj and Panek [17] there was received a very similar value for $\mathrm{N}_{\mathrm{dmax}}$, which was at level 2. 


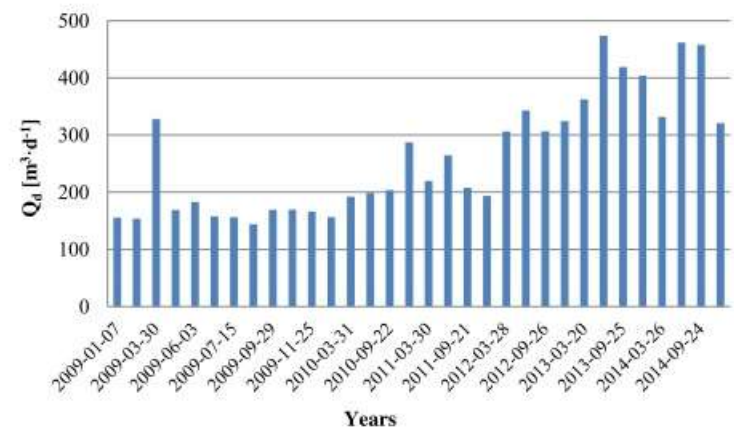

Fig. 2. The amount of sewage inflowing to the wastewater treatment plant in Lusina in the years 2009 -2014.

Table 1. Parameters describing sewage admission into the wastewater treatment plant in Lusina in the years 2009-2014

\begin{tabular}{|c|c|}
\hline $\begin{array}{c}\text { Study } \\
\text { parameter }\end{array}$ & $\begin{array}{c}\text { Parameter } \\
\text { value } \\
{\left[\mathrm{m}^{3} \cdot \mathrm{d}^{-1}\right] ;[-]}\end{array}$ \\
\hline$Q_{\text {dmin }}$ & 144,1 \\
\hline$Q_{\text {avg }}$ & 262,2 \\
\hline$Q_{\text {dmax }}$ & 473,8 \\
\hline $\mathrm{s}$ & 102,9 \\
\hline $\mathrm{V}_{\mathrm{s}}$ & 0,39 \\
\hline Sko & 0,65 \\
\hline Kurt & $-0,84$ \\
\hline $\mathrm{N}_{\mathrm{dmax}}$ & 1,81 \\
\hline
\end{tabular}

The analysis performed for the hydraulic load of the tested wastewater treatment plant was supplemented by the determination of the occurrence of particular inflows frequency and the empirical probability of these values occurrence, using relative rate histograms and empirical distribution. The results of the conducted analysis are presented in the Figure 3.

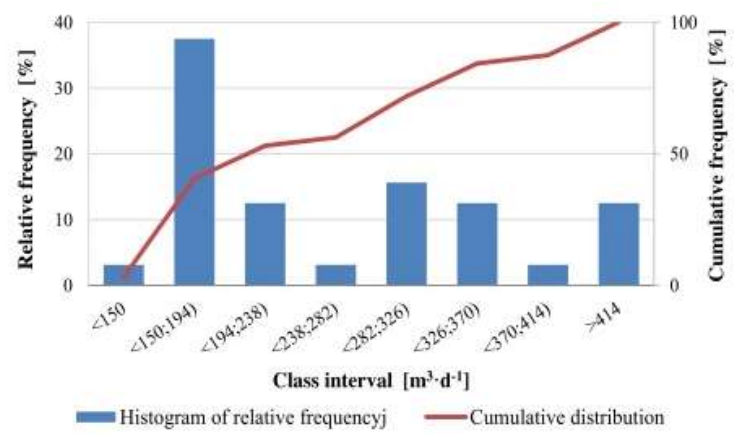

Fig.3. Histogram of relative frequency and empirical cumulative function for the amount of sewage inflowing to the wastewater treatment plant in Lusina in the years 2009 -2014.

For the sewage treatment plant in Lusina, 8 class spans with a spread of $44 \mathrm{~m}^{3} \cdot \mathrm{d}^{-1}$ were determined. In the examined multi-year, the daily volume of sewage flowing into the wastewater treatment plant usually took the value from 150 to $194 \mathrm{~m}^{3} \cdot \mathrm{d}^{-1}$, which accounted for $38 \%$ of all observations. The empirical probability of exceeding the daily capacity of the facility was $0 \%$.
The next stage of the results analysis was to determine descriptive statistics and coefficients of variation for three indicators from the basic group: total suspension, $\mathrm{BOD}_{5}$ and $\mathrm{COD}$, the results of which are presented in the Table 2 .

Table 2. Parameters describing sewage admission into the wastewater treatment plant in Lusina in the years 2009-2014

\begin{tabular}{|c|c|c|c|}
\hline Parameter & $\begin{array}{c}\text { Total } \\
\text { suspension }\end{array}$ & COD & BOD \\
\hline & \multicolumn{3}{|c|}{$\mathrm{g} \cdot \mathrm{m}^{-3} ;[-]$} \\
\hline Minimum & 158 & 394 & 129 \\
\hline Average & 356 & 859 & 374 \\
\hline Maximum & 958 & 1597 & 763 \\
\hline $\begin{array}{c}\text { Standard } \\
\text { deviation }\end{array}$ & 189 & 282 & 145 \\
\hline $\mathrm{V}_{\mathrm{s}}$ & 0,53 & 0,33 & 0,39 \\
\hline
\end{tabular}

During the six-year study period, on the basis of the analyses made for the total suspension, it was observed that the average value of this indicator was $356 \mathrm{~g} \cdot \mathrm{m}^{-3}$, the minimum concentration was $158 \mathrm{~g} \cdot \mathrm{m}^{-3}$, and the maximum was $958 \mathrm{~g} \cdot \mathrm{m}^{-3}$. The calculated value of standard deviation was $189 \mathrm{~g} \cdot \mathrm{m}^{-3}$, and the coefficient of variation according to the adopted scale [18] indicates a high variability of the total suspended solids concentration in wastewater flowing into the treatment plant. The content of organic compounds (expressed as COD) ranged from 394 to $1597 \mathrm{gO}_{2} \cdot \mathrm{m}^{-3}$, with an average value of $859 \mathrm{gO}_{2} \cdot \mathrm{m}^{-3}$. The standard deviation was 282 $\mathrm{gO}_{2} \cdot \mathrm{m}^{-3}$. The value of the coefficient of variation was at the level of 0.33 , which indicates the average variability of COD in raw sewage in the examined period. In the case of the second organic indicator, which was BOD, its value in raw sewage oscillated between 129 and 763 $\mathrm{gO}_{2} \cdot \mathrm{m}^{-3}$, with the average value of $374 \mathrm{gO}_{2} \cdot \mathrm{m}^{-3}$. The calculated value of standard deviation was $189 \mathrm{gO}_{2} \cdot \mathrm{m}^{-3}$, and the coefficient of variation, similarly as in the case of COD, indicates the average variability of this indicator value in sewage flowing into the treatment plant.

In the next stage of the study, there was conducted an analysis of the impact of the amount of sewage flowing into the treatment plant on the values and concentrations of the three analyzed pollution indicators. The results of the dependencies obtained are presented in the Figure 4.

In the case of the first of the analyzed indicators, which is total suspension, it was found that the correlation coefficient between the amount of inflowing wastewater and the concentration of this parameter in sewage was $r_{x y}=-0.53$. On the basis of the adopted scale [17], the obtained level of correlation is assumed as average. The coefficient of determination was at the level of 0.28 , which means that the variation in the total suspended solids concentration is explained in $28 \%$ by the variability of the amount of sewage flowing into the treatment plant. The significance level $\mathrm{p}$ for the $\mathrm{t}$ statistic is less than 0.05 , which means that the correlation coefficient is significantly different from 0 . From the equation describing the regression line shown in the Fig. $4 \mathrm{a}$, it can be concluded that with the increase of volume 
of sewage flowing into the treatment plant by $1 \mathrm{~m}^{3}$ the concentration of total suspension is reduced by $0.53 \mathrm{~g}$. $\mathrm{m}^{-3}$. In the case of the COD indicator (Fig. 4b), it was found that the relation between the volume of sewage and the size of this parameter in raw sewage was at a high level, which is indicated by the value of the correlation coefficient $r_{x y}=-0.66$.

a)

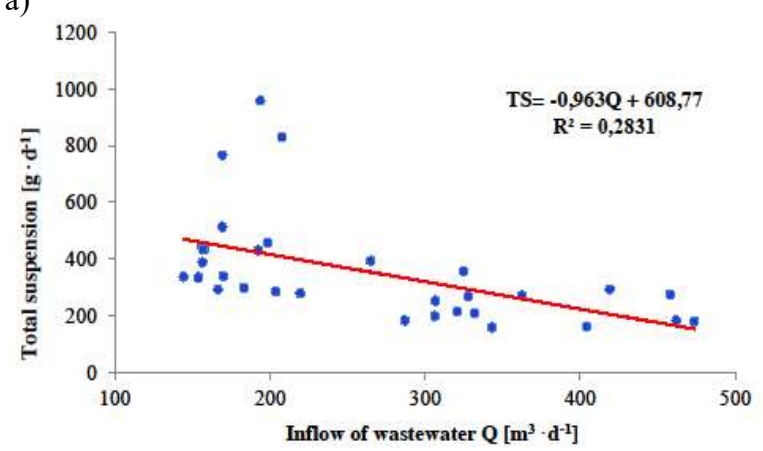

b)

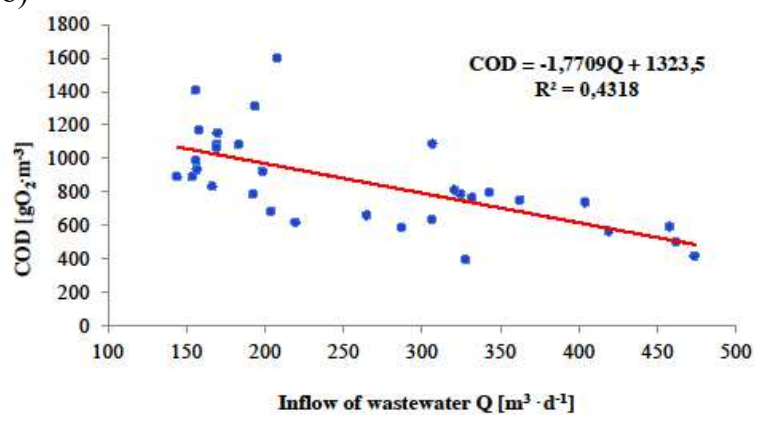

c)

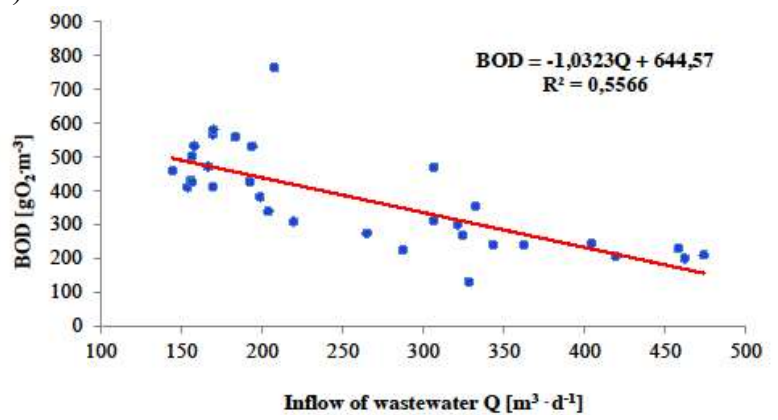

Fig. 4. Relation of concentration of a) total suspension, b) COD and c) BOD in raw sewage from the quantity of inflow wastewater.

The calculated value of test similarity (p) is lower than the assumed significance level $\alpha=0.05$. On this basis, it can be stated that the amount of sewage flowing into the treatment plant has a significant impact on the COD value in raw sewage. The determined linear regression equation for this relation indicates that along with the increase in the amount of inflowing sewage the COD parameters in raw sewage decreases by 1.77 $\mathrm{gO}_{2} \cdot \mathrm{m}^{-3}$. For the second parameter from the abovementioned group, which was $\mathrm{BOD}_{5}$ indicator, the correlation coefficient between the volume of sewage on the inflow and the value of this indicator in wastewater was at the level of $r_{x y}=-0.75$. According to the adopted scale, the correlation at this level is determined as very high. In this case, similarly as before, the significance level $\mathrm{p}$ for the $\mathrm{t}$ statistic is less than 0.05 , which indicates that the correlation coefficient is significantly different from 0 . From the equation describing the regression line shown in the Fig. 4c, it can be inferred that the increase in wastewater volume by $1 \mathrm{~m}^{3}$ causes a decrease in $\mathrm{BOD}_{5}$ by $1.03 \mathrm{gO}_{2} \cdot \mathrm{m}^{-3}$.

On the basis of the analysis regarding the impact of raw sewage amount on the concentration of pollutants in sewage flowing into the treatment plant, there is visible a large correlation between the concentration of organic compounds described by COD and BOD indicators and the amount of wastewater. In the case of total suspension, this relation is less apparent and remains at an average level. Similar results were presented by Bugajski et al. [7], who also stated that in the case of the influence of accidental and infiltration waters on the size of COD and BOD in raw sewage, the correlation is high, and for the concentration of total suspended solids it is at an average level. It is widely known that the increased volume of sewage resulting from the inflow of accidental and infiltration waters to the sewerage system causes the phenomenon of "dilution of sewage", and thus reducing the concentration of pollutants in the inflow. The result of this process is an increase in operating costs and instability of work and processes occurring in the bioreactor. One of the ways to counteract this phenomenon is to control and detect illegal connections of roof gutters to sewerage systems.

\section{Conclusions}

1. The average daily volume of sewage flowing into the treatment plant during the surveyed multi-year was 262.2 $\mathrm{m}^{3} \cdot \mathrm{d}^{-1}$. The coefficient of variation indicates the average variability in the amount of sewage flowing into the treatment plant.

2. In the analyzed multi-year the most frequent amount of incoming sewage was the one from the range of 150 to $194 \mathrm{~m}^{3} \cdot \mathrm{d}^{-1}$, which constituted $38 \%$ of all inflows recorded.

3. In the case of the analyzed pollution indicators from the basic group: total suspended solids, COD and BOD, it was found that with the increase of the amount of sewage in the sewerage system, their concentration and value in sewage flowing into the wastewater treatment plant are reduced.

4. The correlation determining the impact of the amount of sewage on the size of COD and BOD in sewage flowing into the treatment plant was high and very high. Only in the case of total suspension, it was formed at an average level.

5. During the study there has been confirmed the thesis that the increase in sewage volume in the sewerage system causes dilution of wastewater flowing into the treatment plant.

\section{Acknowledgement}

Publication supported by the Polish Ministry of Science and Higher Education as a part of the program of 
activities disseminating science from the project „,Organization of the First International Science Conference - Ecological and Environmental Engineering”, 26-29 June 2018, Kraków.

\section{References}

1. J. Boguniewicz-Zabłocka, A.G. Capodaglio, Economic and Environmental Studies, Vol. 17, No. 4 (44/2017): 1103-1119 (2017)

2. J. Pawełek, Infrastr. Ekol. Ter. Wiej., 2(2): 367-376 (2015)

3. M. Garfi, L. Flores, I. Ferrer, Journal of Cleaner Production, Vol. 161: 211-219 (2017)

4. K. Jóźwiakowski, M. Marzec, J. Fiedurek, A. Kamińska, M. Gajewska, E. Wojciechowska, W. Shubiao, J. Dach, A. Marczuk, A. KowalczykJuśko, Technol. Vol. 173: 357-363 (2017)

5. K. Jóźwiakowski, M. Gajewska, A. Pytka, M. Marzec, M. Gizińska-Górna, A. Jucherski, A. Walczowski, M. Nastawny, A. Kamińska, S. Baran Ecological Engineering, Vol. 98: 290-296 (2017)

6. K. Kurek, D. Młyński, P. Bugajski, E. NowobilskaMajewska, Journal of Ecological Engineering, Vol. 20 (1): 39-45 (2019)

7. P. Bugajski, K. Chmielowski, G. Kaczor, Acta Sci. Pol. Formatio Circumiectus 15(2): 3-11 (2016)

8. H. Obarska-Pempkowiak, K. Kołecka, M. Gajewska, E. Wojciechowska, A. Ostojski, Rocz. Ochr. Środ., 17, 585-602 (2015)
9. K. Jóźwiakowski, A. Pytka, M. Marzec, M. Gizińska, J. Dąbek, B. Głaz, A. Sławińska, Infrastr. Ekol. Ter. Wiej., 3(1), 73-86 (2012)

10. G. Kaczor, Infrastr. Ekol. Ter. Wiej., 3(IV): 179191 (2012)

11. D. Zdebik, K. Korczak, Praca naukowa GIG. Górnictwo i Środowisko/ Główny Instytut Górnictwa, 1: 73-89 (2010)

12. R. Hreiz, M.A. Latifi, N. Roche, Chemical Engineering Journal, Vol. 281: 900-920 (2015)

13. G. Kaczor, Acta Sci. Pol. Formatio Circumiectus 10(2): 27-34 (2011)

14. D. Młyński, K. Chmielowski, Journal of Water and Land Development, 28 (I-III): 61-67(2016)

15. Z. Heidrich Z. Domestic sewage treatment systems. Guide. Warszawa. CIOB: 220 (2010)

16. A. Stanisz, Przystępny kurs statystyki t.(I). Wydawnictwo StatSoft polska Sp. z o.o. Kraków (1998)

17. S. Myszograj, E. Panek, Gaz, Woda i Technika Sanitarna, 5:9-12 (2007)

18. J. Mucha, Metody geostatystyczne w dokumentowaniu złóż. Kraków. Wydawnictwo AGH: 155 (1994)

19. Siwiec T., Reczek L., Michel M.M., Gut B., HawerStrojek P., Czajkowska J., Jóźwiakowski K., Gajewska M., Bugajski P. (2018) Archives of Environmental Protection, vol. 44, no. 4, pp. 50-57. 